\title{
A Study of Seroprevalence of Hepatitis B in HIV Positive Cases of ICTC at Tertiary Care Centre
}

\author{
Isha Mehta $^{1}$, Anil Chaudhary ${ }^{2 *}$ and G.U. Kavathia ${ }^{3}$ \\ ${ }^{1}$ P.D.U Medical College, Rajkot, Gujarat, India \\ ${ }^{2}$ GMERS Medical College, Gotri, Vadodara, India \\ ${ }^{3}$ P.D.U Medical College, Rajkot, India \\ *Corresponding author
}

\section{A B S T R A C T}

\begin{tabular}{|l|}
\hline Keyw or d s \\
HIV, Hepatitis B, \\
Seroprevalance \\
\hline Article Info \\
\hline Accepted: \\
04 August 2018 \\
Available Online: \\
10 September 2018 \\
\hline \hline
\end{tabular}

The study was conducted to assess the extent of seropositivity of Hepatitis B among HIV positive patients at tertiary care hospital in Rajkot from JUNE 2016 to MAY 2017 and evaluate the need of routine screening for this infection among such patients. The samples were tested for HIV as per Strategy III of National AIDS control organization by using different system of testing to establish diagnosis of HIV. The HbsAg test is a one-step immunochromatographic assay based on the antigen capture or "Sandwich" principle. Out of total 300 HIV positive patients, $69.67 \%$ were male and $30.00 \%$ were female. Only one was transgender. Out of 300 samples tested, 7(2.33\%) samples were positive for HBsAg with $6(2.87 \%)$ of male and $1(1.11 \%)$ of female patients. Higher prevalence was observed in age group of 31-60yrs and in male patients. We believe our data could help health professionals to deal better with HIV infected patients. We also believe our data reinforces the need of prevention programs on HIV transmission, which also lead to reduction in prevalence of Hepatitis B.

\section{Introduction}

Human Immunodeficiency Virus (HIV) causes Acquired Immunodeficiency Syndrome (AIDS). It is a serious disorder of the immune system in which the body's normal defenses against infection break down, leaving it vulnerable to a host of life-threatening infections (Sejul Antala, 2006). Almost 35 years have now elapsed. Thirty-five years, in which HIV infection has changed from a fatal condition to a manageable chronic illness. Thirty-five years, in which the development of antiretroviral therapy (ART) has been one of the dramatic advances in the history of medicine. However, for the vast majority of people living with HIV/AIDS, ART is still light years away largely inaccessible in resource-poor countries where HIV continues to devastate families, communities and societies, especially the poor and the socially marginalized (Harshakumar, 2011).

Hepatitis B virus is the most important causative agent of transfusion-associated hepatitis. Humans are the only reservoir of 
Hepatitis B virus (HBV). Blumberg et al., discovered Hepatitis B virus in 1965 in the serum of an Australian aborigine and thus its antigen is also called as Australia antigen. Dr. Baruch Blumberg awarded The Noble Prize in Physiology and Medicine in 1976 for discovery of Hepatitis B virus. The virus particle (virion) is a small complex doubleshelled structure having an external diameter of $42 \mathrm{~nm}$ with a nucleocapsid core and lipoprotein coat. This particle was first discovered by Dane and his colleagues in 1970 and thus is called Dane particle. It represents the complete HBV. The nucleocapsid core is $27 \mathrm{~nm}$ in diameter. It replicates in the nuclei of infected hepatocyts and possesses a distinct antigen called hepatitis core antigen ( $\mathrm{HBcAg}$ ). The virion core antigen contains DNA polymerase and double stranded DNA molecule (Mandell et al., William Lee, 1997; Sheila Sherlock, 1989; Krugman et al., 1967; Krugman and Giles, 1970; Blumberg et al., 1965).

Both HBV and HIV share similar mode of transmission and risk factors (Ansa et al., 2002), HIV-infected people are frequently coinfected with HBV. Hepatitis B virus infection is associated with significant morbidity and mortality in patients with HIV infection. (Piliero and Faragon, 2002; Thio et al., 2002) Co-infection of HIV with HBV affects change number of patients worldwide. (Nelson et al., 2002) Among people with HIV, 70 to $90 \%$ have been found to have HBV exposure, while 10 to $15 \%$ have chronic HBV infection. (Seattle Treatment Education Project, 2002) Although, very few co-infection studies have been carried out in Africa but since subSaharan Africa is a home of about 29.4 million HIV infected people, high HIV/HBV confection is expected. However results are contradictory. While in Kenya, 32(78\%) out of 41 patients with AIDS had serological evidence of exposure to HBV (Ogutu et al., 1990), a study among pregnant women attending ante-natal clinics in Burkina Faso, showed a low co-infection rate of $0.88 \%$ (Dao et al., 2001).

\section{Materials and Methods}

This study is undertaken to determine seropositivity rate of Hepatitis $B$ virus surface antigen (HBsAg) among Human Immunodeficiency Virus (HIV) reactive cases attending Integrated Counselling and Testing Centre (ICTC), P. D. U. Goverment Medical College \& Hospital, Rajkot. Serums from 300 HIV positive cases were collected from June 2016 to May 2017. These samples were already tested for HIV as per Strategy III of National AIDS control organization by using different system of testing to establish diagnosis of HIV.

Test- 1 - (Comb Aids Test)

Test-2- (Meriscreen Immunochromatographic Card Test)

\section{Test-3 - (AIDSCAN Trispot test)}

Care has been taken to maintain confidentiality regarding HIV status of an individual and all samples were collected after pretest counselling by counsellor at ICTC centre. Reports were dispatched after post test counselling of an individual by maintaining confidentiality between counsellor and individual tested. No one was allowed to access patient's personal data except Age, Sex \& Identification Mark that have to be written on laboratory form. Counsellor at ICTC centre gave all patients unique identification number.

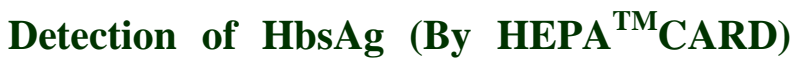 Immunochromatographic Assay}

HEPA ${ }^{\mathrm{TM}}$ CARD is a qualtitative test based on immunochromatographiy sandwich principle. The test card includes a combination of 
monoclonal anti-body gold conjugate (colloidal gold) and monoclonal solid phase antibodies which selectively binds Hepatitis B surface antigen with high degree of sensitivity.

\section{Results and Discussion}

Out of total $300 \mathrm{HIV}$ positive patients, $69.67 \%$ were male and $30.00 \%$ were female. Only one was transgender. Out of 300 samples tested, 7(2.33\%) samples were positive for $\mathrm{HBsAg}$ with $6(2.87 \%)$ of male and $1(1.11 \%)$ of female patients. Higher prevalence was observed in age group of 31-60yrs and in male patients. Table 1 and 3 shows that out of total 300 HIV positive patients, Only 7 patients were HBV positive in which 2 patients were positive in each age group of 31-40 yrs, 41$50 y r s$ and 51-60 yrs. Only 1 patient was positive in 21-30 yrs age group (Table 5).

Table 2 and 4 shows that out of total 300 HIV positive patients, Only 7 patients were HBV positive in which Majority i.e. 6 were male and only 1 was female. HBsAg prevalence among HIV positive cases varies from $0.70 \%$ to $38.60 \%$ in different studies.

Present study shows HBsAg prevalence rate of $2.33 \%$ among HIV infected patients. This is nearly similar to findings of $\mathrm{P}$ SantiagoMunoz, Shazia M Ahsanand Rui Alberto. The study by Philippa C shows very low prevalence rate of just $0.70 \%$. The study by Maria Cássia $\mathbf{J}$ shows prevalence rate as high as $38.6 \%$, which is very high compared to present study. Indian studies by Dhanvijay AG and Tankhiwale SS shows prevalence rate of $28 \%$ and $30.91 \%$ respectively among HIV positive patients. In present study, difference in prevalence may be due to variation in epidemiological, other risk factors and methods of testing among various studies. The fact that HIV and HBV share a common mode of transmission (predominantly blood and high risk sexual behaviors) attributes to the significant association between $\mathrm{HBV}$ and HIV.

Table.1 HBV Prevalence among HIV positive cases in various age groups

\begin{tabular}{|c|c|c|c|c|c|c|}
\hline \multirow{2}{*}{$\begin{array}{l}\text { Age } \\
\text { (Years) }\end{array}$} & \multicolumn{2}{|c|}{ Positive } & \multicolumn{2}{|c|}{ Negative } & \multicolumn{2}{|c|}{ Total } \\
\hline & No. & $\%$ & No. & $\%$ & No. & $\%$ \\
\hline 0 - 10 & 00 & 00.00 & 09 & 100.00 & 09 & $03.00 \%$ \\
\hline $11-20$ & 00 & 00.00 & 15 & 100.00 & 15 & $05.00 \%$ \\
\hline $21-30$ & 01 & 01.54 & 64 & 98.46 & 65 & $21.67 \%$ \\
\hline $31-40$ & 02 & 02.13 & 92 & 97.87 & 94 & $31.33 \%$ \\
\hline $41-50$ & 02 & 03.30 & 64 & 96.70 & 66 & $22.00 \%$ \\
\hline $51-60$ & 02 & 05.00 & 38 & 95.00 & 40 & $13.33 \%$ \\
\hline$\geq 61$ & 00 & 00.00 & 11 & 100.00 & 11 & $03.67 \%$ \\
\hline Total & 07 & $2.33 \%$ & 293 & $97.67 \%$ & 300 & $100 \%$ \\
\hline
\end{tabular}

Table.2 HBV Prevalence among HIV positive cases according to sex

\begin{tabular}{|l|l|l|l|l|l|l|}
\hline Sex & Positive & \multicolumn{3}{l|}{ Negative } & Total \\
& No. & $\%$ & No. & \% & No. & \% \\
\hline Male & $\mathbf{0 6}$ & $\mathbf{0 2 . 8 7}$ & $\mathbf{2 0 3}$ & $\mathbf{9 7 . 1 3}$ & $\mathbf{2 0 9}$ & $\mathbf{6 9 . 6 7 \%}$ \\
\hline Female & $\mathbf{0 1}$ & $\mathbf{0 1 . 1 1}$ & $\mathbf{8 9}$ & $\mathbf{9 8 . 8 9}$ & $\mathbf{9 0}$ & $\mathbf{3 0 . 0 0 \%}$ \\
\hline Transgender & $\mathbf{0 0}$ & $\mathbf{0 0 . 0 0}$ & $\mathbf{0 1}$ & $\mathbf{1 0 0 . 0 0}$ & $\mathbf{0 1}$ & $\mathbf{0 0 . 3 3 \%}$ \\
\hline Total & $\mathbf{0 7}$ & $\mathbf{2 . 3 3 \%}$ & $\mathbf{2 9 3}$ & $\mathbf{9 7 . 6 7 \%}$ & $\mathbf{3 0 0}$ & $\mathbf{1 0 0 \%}$ \\
\hline
\end{tabular}


Table.3 Comparison of HBsAg prevalence among HIV positive cases

\begin{tabular}{|c|c|c|c|}
\hline Sr. No. & Study & Total Sample & $\begin{array}{c}\text { HBsAg } \\
\text { positive (\%) }\end{array}$ \\
\hline 1 & Philippa C & 1022 & $72(0.70)$ \\
\hline 2 & P Santiago-Munoz & 455 & $07(1.5)$ \\
\hline 3 & PRESENT STUDY & $\mathbf{3 0 0}$ & $\mathbf{0 7}(\mathbf{2 . 3 3})$ \\
\hline 4 & Shazia M Ahsan & 200 & $07(3.5)$ \\
\hline 5 & Rui Alberto & 1000 & $37(3.70)$ \\
\hline 6 & Carmen Pittman & 2844 & $143(5.06)$ \\
\hline 7 & Pavan MH & 226 & $12(5.30)$ \\
\hline 8 & Maria Helena P & 226 & $12(5.31)$ \\
\hline 9 & Treitinger A & 93 & $23(24.30)$ \\
\hline 10 & N Shire & 3867 & $967(25.01)$ \\
\hline 11 & Uneke & 490 & $127(25.92)$ \\
\hline 12 & Mustapha & 200 & $53(26.50)$ \\
\hline 13 & Dhanvijay AG & 175 & $49(28.00)$ \\
\hline 14 & Tankhiwale SS & 110 & $34(30.91)$ \\
\hline & Maria Cássia J & 1693 & $654(38.60)$ \\
\hline
\end{tabular}

Table.4 Comparison of HBsAg Prevalence according to Sex among HIV positive cases

\begin{tabular}{|l|c|c|}
\hline SEX & $\begin{array}{c}\text { Present Study } \\
\text { Positive \% }\end{array}$ & $\begin{array}{c}\text { Mustapha } \\
\text { (Mustapha and } \\
\text { Jibrin, 2004) } \\
\text { Positive \% }\end{array}$ \\
\hline Male & $2.87 \%$ & $2.7 \%$ \\
\hline Female & $1.11 \%$ & $2.2 \%$ \\
\hline
\end{tabular}

Table.5 Comparison of HBsAg prevalence according to age group among HIV positive cases

\begin{tabular}{|c|c|c|c|c|c|c|c|c|}
\hline \multirow[t]{2}{*}{ Age Group } & \multicolumn{2}{|c|}{$\begin{array}{c}\text { Mustapha } \\
\text { (Mustapha and } \\
\text { Jibrin, 2004) }\end{array}$} & \multicolumn{2}{|c|}{$\begin{array}{c}\text { Uneka (Uneke et } \\
a l ., 2005 \text { ) }\end{array}$} & \multicolumn{2}{|c|}{$\begin{array}{l}\text { Dr. Antala (Sejul } \\
\text { Antala, 2006) }\end{array}$} & \multicolumn{2}{|c|}{ Present Study } \\
\hline & $\begin{array}{l}\text { Number } \\
\text { (positive) }\end{array}$ & $\%$ & $\begin{array}{l}\text { Number } \\
\text { (positive) }\end{array}$ & $\%$ & $\begin{array}{l}\text { Number } \\
\text { (positive) }\end{array}$ & $\%$ & $\begin{array}{l}\text { Number } \\
\text { (positive) }\end{array}$ & $\%$ \\
\hline$\leq 20$ & $00(05)$ & 00.0 & $04(015)$ & 26.67 & $00(11)$ & 00.00 & 00 (19) & 0 \\
\hline $21-30$ & $14(50)$ & 28.0 & 40 (184) & 27.74 & $18(85)$ & 21.18 & $01(65)$ & 1.53 \\
\hline $31-40$ & $17(79)$ & 21.52 & $53(188)$ & 28.19 & $14(71)$ & 19.72 & $02(94)$ & 2.13 \\
\hline $41-50$ & $24(48)$ & 50.00 & $19(078)$ & 24.36 & $05(26)$ & 19.23 & $02(66)$ & 3.3 \\
\hline$\geq 51$ & $02(18)$ & 11.11 & $11(025)$ & 44.00 & $02(07)$ & 28.57 & $02(51)$ & 3.92 \\
\hline TOTAL & $53(200)$ & 26.50 & $127(490)$ & 25.92 & $39(200)$ & 19.50 & $07(300)$ & 2.33 \\
\hline
\end{tabular}


The rate of co-infection in males $(2.87 \%)$ is higher than females $(1.11 \%)$, which is comparable to (Mustapha and Jibrin, 2004) having males $(2.7 \%)$ and females $(2.2 \%)$. The reason for this disparity is not clear. However it is known that males are less likely to clear HBsAg and have a higher risk of progression to cirrhosis.

Age wise distribution showed that the higher rate of $\mathrm{HBsAg}$ prevalence is found among $\geq 51(3.92 \%)$ age group which is also noticed in study of Mustapha and Uneke.

In keeping with the endemic nature of $\mathrm{HBV}$ in this environment, $\mathrm{HBsAg}$ positivity is found in all the age groups except in the $\leq 20$ years age group in which no cases were recorded in present study as well as by Mustaphaand Dr. Antalabut Uneke shows prevalence rate of $26.67 \%$ in this age group.

The most likely explanation for this observation is the low number of subjects in that age group compare to other age groups. Highest prevalence is observed among age group $\geq 51(3.92 \%)$, which may be due to more chances of exposure to various risk factor over such a long period of life.

Out of 300 samples tested, 7(2.33\%) samples were positive for HBsAg with $6(2.87 \%$ ) of male and $1(1.11 \%)$ of female patients. Higher prevalance was observed in age group of 31$60 y$ rs and in male patients. Our results are comparable with some of the studies conducted in India and abroad.

We believe our data could help health professionals to deal better with HIV infected patients.

We also believe our data reinforces the need of prevention programs on HIV transmission, which also lead to reduction in prevalence of HBV.

\section{References}

Ansa VO, Udoma EJ, Umoh MS, Anah MU: Occupational risk of infection by human immunodeficiency and hepatitis B viruses among health workers in Sougheastern Nigeria. East Afr Med. J. 2002; 79(5): 254-6.

Blumberg BS, Alter HJ, Visnich S. A. "new" antigen in leukemia sera: JAMA. 191: 514. 1965.

Dao B, Nacro B, Dahourou H, et al., HIV infectin and HBV co-infection: survery of prevalence in pregnant women in Burkina Faso. Rev. Med. Brux, 2001; 2: 83-86.

Harshakumar, Study on TB patients who are HIV positive and its corelation with CD4 count. (2011) (http://14.139. 159.4:8080/jspui/bitstream/123456789/ 7771/1/Harsha\%20Kumar\%20H\%20N. pdf)

Krugman S, and Giles JP. Viral Hepatitis: New light on an old disease: JAMA. 212: 1019. 1970.

Krugman S, Giles JP, Hammon J. Evidence for two distinctive clinical, epidemiological \& immunological types of Infection: JAMA. 200: 365. 1967.

Mandell, Douglas and Bennett, Principal and practices of Infectious diseases. $7^{\text {th }}$ edition.

Mustapha, S. K., and Y.B. Jibrin. The Prevalence of Hepatitis B Surface Antigenaemia in Patients with Human Immunodeficiency Virus (HIV) Infection in Gombe, Nigeria; Annals of African Medicine. Vol. 3, No. 1; 2004: $10-12$

Nelson M: Updates on Research studies on HIV co-infection with hepatitis B and C. XIV International AIDS conference. July 7-12, 2002. Spain, Barcelona.

Ogutu EO, Amayo EO, Okoth F, Luce GN: The prevalence of $\mathrm{HbsAg}$, anti $\mathrm{HBs}$ and 
anti $\mathrm{HBC}$ in patients with AIDS. East Afr Med J. 1990; 65(5): 355-8.

Piliero PJ, and Faragon JJ: Case report. Hepatitis B Virus and HIV co-infection AIDS Read. 2002; 12(10): 443-448-51.

Seattle Treatment Education Project (STEP): Hepatitis co-infection; HIV/HBV coinfection. Issue, March 28, 2002; 1: 36.

Sejul Antala, study on seroprevalance of hepatitis B, hepatitis C, and Syphilis in HIV positive patients INICTC, Rajkot. (2006)

Sheila Sherlock. Disease of liver \& Biliary system. $8^{\text {th }}$ edition 1989.
Thio CL, Seabearg EC, Skolasky R: HBV and the risk for liver-related mortality in the multicenter cohort study. Lancet. 2002; 360: 1921-6.

Uneke, C.J., O Ogbu, PU Inyama, GI Anyanwu, MO Njoku, JH Idoko; Prevalence of hepatitis-B surface antigen among blood donors and human immunodeficiency virus-infected patients in, Jos, Nigeria; Mem Inst Oswaldo Cruz, Rio de Janeiro, Vol. 100(1): 13-16, February 2005

William Lee. Hepatitis B Virus Infection. N Engl J Med 24:337, 1997.

\section{How to cite this article:}

Isha Mehta, Anil Chaudhary and Kavathia, G.U. 2018. A Study of Seroprevalence of Hepatitis B in HIV Positive Cases of ICTC at Tertiary Care Centre. Int.J.Curr.Microbiol.App.Sci. 7(09): 220-225. doi: https://doi.org/10.20546/ijcmas.2018.709.028 